Field Convergence between Technical Writers and Technical Translators:

Consequences for Training Institutions

Marusca Gnecchi

European Commission, Joint Research Centre

Marusca.Gnecchi@ec.europa.eu

maruscagnecchi@libero.it

Bruce Maylath

North Dakota State University

Dept. 2320

P.O. Box 6050

Fargo, ND, 58108-6050, USA

$1-701-231-7176$

bruce.maylath@ndsu.edu

Birthe Mousten

Aarhus School of Business, Aarhus University

Fuglesangs Allé 4

DK-8210 Aarhus V, Denmark

4589486688

$\underline{\text { bmo@asb.dk }}$ 
Federica Scarpa

Università degli Studi di Trieste

SSLMIT, Via Filzi 14, 34132 Trieste, Italy

39-040-5582314

fscarpa@units.it

Sonia Vandepitte

University College Ghent Translation Studies

Groot-Brittanniëlaan 45

B-9000 Ghent, Belgium

32 (9) 2249725

sonia.vandepitte@hogent.be

Marusca Gnecchi obtained her degree in translation from the University of Trieste, Italy, in 2001, with a thesis on specialist translation and technical communication. She has worked in the language industry and international sales and presented at the fourth European Society for Translation Studies congress in Lisbon (2004) and the INTECOM FORUM conference in Milan (2003). She is currently employed with the European Commission, Joint Research Centre, in Ispra, Italy.

Bruce Maylath is a professor of English at North Dakota State University, USA, where he teaches courses in professional communication and linguistics. A contributor to many professional journals, his current research takes up translation issues in technical communication. Along with Dale Sullivan 
and Russel Hirst, he is the co-editor of Revisiting the Past through Rhetorics of Memory and Amnesia (Cambridge Scholars Publishing, 2010).

Birthe Mousten lectures at the Aarhus School of Business, Aarhus University, Denmark. She teaches courses in English for science and technology and web-related text production at the university, as well as courses for trade and industry. She recently published two coauthored chapters in StarkeMeyerring and Wilson's Designing Globally Networked Learning Environment —Visionary Partnerships, Policies, and Pedagogies.

Federica Scarpa is a professor of English and translation at the University of Trieste, Italy, where she teaches courses in specialist translation from English to Italian and translation theory. She is also director of the Department of Language, Interpreting and Translation Sciences. She has published on special languages and specialist training. The French translation of her book on specialized translation (La traduction spécialisée) was published in 2010 by University of Ottawa Press.

Sonia Vandepitte is a lecturer of English. She teaches English grammar and translation from and into English and coaches student translation businesses. She has published on intonation, causal expressions, knowledge retrieval, methodological issues in translation studies, translation competences, and anticipation in interpreting and international teaching projects. She supervises research projects on parallel and comparable corpora, a Dutch clarity tool, electronic feedback in ESL-learning and linguistic aspects in the translation process. 


\title{
Field Convergence between Technical Writers and Technical Translators: Consequences for Training Institutions
}

\begin{abstract}
As translation of technical documents continues to grow rapidly and translation becomes more automated, the roles of professional communicators and translators appear to be converging. This article updates preliminary findings first presented at the 2008 International Professional Communication Conference in Montreal. It analyzes trends revealed from recent surveys and recommends follow-up research to determine if the trends may continue and become entrenched. The authors conclude with recommendations for academic programs interested in adjusting to the trends.
\end{abstract}

Index Terms-Academic programs, documentation, professional communication, technical communication, technical translation. 
Should technical writers and translators be cross-trained? Indeed, will their roles be distinguishable in the future? The need for internationalization and the concurrent integration of translation in the global information process appears to be accelerating the convergence of the two profiles of professional or technical author/communicator and specialist translator. The emerging hybrid profiles — combining language, writing, and multilingual communication skills - corroborate the image of the "ecosystem" for the global linguistic industry, where an increasing interdependence among different operators is required [1].

In Europe, professional and technical communicators frequently start their careers as translators and then—-sometimes after having taken a specialized course (e.g., Hofer [2])— migrate to technical authorship, a trend identified earlier by Groethuysen and Gnecchi in a 2003 presentation at INTECOM's FORUM [3], [4]. The inclusion of technical communication in translator training programs has already been advocated by translation scholars like Byrne, who considers the understanding of how technical texts are produced as essential to achieving the highest standards of quality in the target language [5]. Likewise, many academic programs in technical communication, such as the one at Belgium's University of Antwerp, require their graduates to write competently in two, three, or more languages.

In North America, academic programs in professional/technical/scientific communication (PTSC) have been prone to keep their distance from multilanguage writing and translation, even though convergence is taking place just beyond their doors in the businesses that might hire their graduates. Maylath pointed out this apparent wariness (or, perhaps, obliviousness) in a 2004 presentation to the Association of Teachers of Technical Writing (ATTW) [6]. Drawing on results from a survey of that year, the presentation noted 
which universities, technical communication curricula, and course matter were best positioned to meet this trend.

\section{Model Curricula}

Some academic programs in the US are taking steps to prepare students by offering a course in international technical communication. The addition of a single course, however, seems to be a minimal step. Other programs are going further. The University of Wisconsin, Milwaukee, for example, has been able to couple its technical writing program with its foreign language programs to create a certificate in translation studies, thus merging the two fields [7]. In the same state's higher education system, the technical communication program at the University of Wisconsin, Stout, demonstrates how a curriculum can be fleshed out beyond a single, minimal course so that students receive gradually mounting instruction throughout their degree in technical documentation destined for translation. Founded in 2000, the curriculum has been updated thrice, each time adding more topics and projects to give students more knowledge and experience in communicating internationally. The curriculum consists of the following:

1. Learning to prepare texts for translation in the Technical Writing course.

2. Collaborating on the above texts with students studying translation in Europe as the texts are translated for overseas audiences [8]-[10].

3. Learning the elements of editing for global contexts in the Editing Practices and Processes course, including becoming familiar with British English.

4. Editing technical texts in the senior capstone Technical Communication and Consulting course to render the texts in idiomatic American English, in collaboration 
with European students who have already translated the texts from their native language into (more or less) British English.

5. Designing wordless or minimal-word instructions for international use in the Document Design course.

6. Taking full courses in Intercultural Communication and International Technical Communication.

7. Providing opportunities to study abroad, with the fall semester of the junior year blocked out in the suggested course sequence.

Similar developments are taking place at North Dakota State University, whose English Department has joined the collaborative network of the Trans-Atlantic Project. (Chapters describing both the operation and the theories behind the Trans-Atlantic Project appear in Designing Globally Networked Learning Environments [9], [10] and the 2005 Proceedings of the International Professional Communication Conference [8].) Even with preparation of this sort, US students may find that their opportunities will become more limited unless they master a second language. Though few students at UW-Stout or North Dakota State can be said to have mastered a second language by the time they graduate, those who do have found themselves quite marketable. For instance, one such UW-Stout student completed an internship at a translation company after gaining a command of Spanish by studying abroad in Mexico and completing a minor in Spanish. When she graduated, she landed a job as project manager for one of the largest documentation and translation firms on America's West Coast. 


\section{EVOLVING EUROPEAN StANDARDS}

Another angle comes into view in Europe with the relatively new Comité Européen de Normalisation (CEN) standard EN 15038. Adopted in 2006, this standard - the first ever to be devoted specifically to translation service providers—-specifies how a translation can follow the path of translation to revision to review in its text travel from one market to another, where revision is a bilingual check and review is a monolingual check of the translated text. For a person to possess all the skills needed under the CEN standard, translation is no longer enough. Revision skills are needed to change a (machine-)translated text against the background of the source text as the two texts are compared; reviewing skills are needed when the text is changed to adapt it to the target locale and culture-including omitting existing content and/or creating new content, thus transgressing the border between translation and PTSC.

As Mousten pointed out in 2007, this work process delineated by the CEN standard has led in two directions - one positive, one negative, respectively: (1) a much more hands-on approach to the target market, because the reviewing stage cuts the dependence on the source text; (2) the presence of rather grave errors because of misunderstandings of the content, due precisely to the severing of the link to the source text [11].

For academic programs and translation curricula the link is clear: Translation scholars have not only argued for revision tasks in translation curricula but also, more broadly, for teaching editing skills (e.g., [12]-[15]) to avoid the "significant risk that revision may not always improve final text quality" [16, p. 49]. For those translating technical texts and using machine translation systems, pre- and post-editing skills have been recommended [17]. 


\section{LITERATURE REVIEW}

With the cooperation of the European Commission's Directorate General for Translation, European translation institutions have launched a European Master of Translation program "to serve as a reference for curriculum planning, assessment and comparison" [18]. In translation studies, the use of corpora in translation training has been much promoted in [19]-[23]. However, questions like ours on the roles of translators have been raised from other quarters, too. Describing the multifaceted character of professional translation, Gouadec stresses the need for translation curricula to account for more competencies than traditional curricula have provided [24]. In an early, influential study, Risku investigated how and why translators have migrated to technical communication and/or usability, pointing out that such migration is possible only because of a common competency denominator, that is, both translation and technical communication involve cooperative text design where source texts and knowledge sources combine to create technical documents for a certain target group [25], [26]. Most translators' skills corresponded with technical communicators' skills, but technical communicators were much more used to obtaining information from subject-matter experts than translators [25]. Such findings beckon for more interview training in translation curricula if translation students are to perform also as technical writers, and they pose the question: What differences exist between the academic curricula of professional communicators and technical translators? Risku notes that technical writers learn argumentation and content determination, selection, and structuring, whereas technical translators focus their learning on linguistic and terminological research [25].

Our experience, however, suggests that such a difference is not as clear-cut as the respondents in Risku's study see it. Within linguistic studies, genre (text-type) analysis [27], 
currently part of many universities' technical translation curricula, is in fact concerned with argumentation ("the analysis of the various moves that writers use to write a given section of a text or to develop their argument" [28, p. 219]) and determination of content. Moreover, knowledge management, also part of technical translation curricula, deals with content selection and structuring. In her study of multilingual text travel, Mousten received the following response from a translator about her responsibility for PTSC in a global company:

Actually, I am just asked to translate it. But I feel that I have a large responsibility to comment on the contents as well if anything seems strange to me. I am not asked to do that directly, but I'm doing it anyway, and I feel that people listen to what I say, and that I have the freedom to change the text. [29, p. 204]

The same study showed that translation strategies involved "proper" translation as well as content creation, adaptation, and removal in a multilingual flow on a company's website [29, p. 235]. These results are in line with the view, advocated by many (e.g., [30], [31]), of translation as a professional activity of intercultural communication rather than a process of linguistic transfer. Paretti, McNair, and Holloway-Attaway describe the business practice of previous team relationships growing into distributed work relationships [32]. The distribution of team members across borders and functions calls for new ways of thinking and organizing. Likewise, Melton sees translation integrated with PTSC [33]. In his view, successful translation equals rhetorical re-creation. He illustrates with a US-Japanese context, where context is defined as being cultural, professional, and collaborative. At a training seminar, a phrase appearing in the US version is "formula for your results." In the Japanese version, it is 
translated as "where do you put your weight in your conversation?" The difference in the expressions' contents reflects the results-oriented US culture and process-oriented Japanese culture [33]. A dual cultural background is rare, however, and even a person with it does not automatically gain insights into two cultures. Melton adds that translation competence depends on the ability to build team relationships and rapport [33].

Team-building relationships as a basis for ongoing, fruitful dialogue in global communication have been discussed widely in recent years [4], [6], [8]-[10], [25], [26], [29]. Paretti, McNair, and Holloway-Attaway demonstrate the need to identify common goals [32]. Partners in the Trans-Atlantic Project have repeatedly stressed common goal identification through students' prelearning and postlearning reports and translation briefs [9].

\section{Surveys of Professional Communicators and Translators}

To determine the degree to which migration trends have persisted and to hypothesize whether and how they will continue, the authors constructed surveys of professionals in their fields. Surveys were deemed the best method when the authors determined that only the professionals themselves would be able to identify fully and quickly their own career paths, education (including cross-training), and work assignments. Moreover, the authors recognized that webbased surveys could quickly and easily reach the most professionals across two continents, as recent research has revealed [34], [35]. To reach professionals, the authors constructed two surveys: one for North America, where professional communicators and translators still tend to identify themselves chiefly in one category or the other, and one for Europe, where the categories have seemed to converge more quickly and longer. Thus, the surveys were designed distinctively for each continent: differing locales called for localizing the surveys. The survey 
for North America focused primarily on roles and activities to see how each category's members were involved in the activities that formerly were assigned much more strictly to one category or the other. (See Appendix A.) The survey for Europe focused mainly on the bilingual nature of translators' work and the degree to which they are involved in writing and editing, as well as translating. (See Appendix B.) Although different, both surveys had the same function: to gauge whether and to what degree the fields of PTSC and translation may be converging.

The North American Survey Methods The North American survey (Appendix A), titled "Professional Communication and Translation in North America," aimed to answer the following questions:

1. Have the roles of professional communicator and technical translator been converging in the US and Canada?

2. Have translators' roles expanded to include source-text authorship? Have technical communicators' roles expanded with the addition of translation projects?

3. Would translators and technical authors need or benefit from cross-training during their studies and later on during employment? What in particular should instructors include from each of the two fields when designing academic cross-training?

To trace the factors that might affect responses to these questions, the survey also posed questions about participants' demographic information, employment, and educational background. 
The survey was aimed at both translators and technical communicators whose work was based primarily in North America. Email listservs were used to send invitations specifically to the following groups, though recipients were asked to distribute the invitation widely:

- The Society for Technical Communication's Academic Community Special Interest Group [36]

- The Association of Teachers of Technical Writing [37]

- The Canadian Association of Teachers of Technical Writing/l'Association Canadienne des Professeurs de Rédaction Technique et Scientifique [38]

- The Council for Programs in Technical and Scientific Communication [39]

- The American Translation Association language divisions [40]

- Attendees of the Translation World conference [41]

- The Globalization and Localization Association [42]

- AILIA The Language Industry Association / l'Association de l'Industrie de la Langue [43]

The North American Survey Results The North American survey, accessible on SurveyMonkey.com for a little over four weeks in April and May 2008, collected responses from 88 participants in 13 nations [44]. Of these, 52 were from the US and 5 from Canada. Except for France, all other countries were represented by one respondent or, at most, 2 (India and UK). France accounted for 17 respondents. Because the survey invitation explained that it was intended for those whose work occurs primarily in North America, and another survey was available for those whose work occurs primarily in Europe, we do not know if (a) such 
respondents who did not list Canada or US are originally from other countries but now live and work in North America (a common and widespread phenomenon, given the continent's immigration record), (b) such respondents live outside North America but do contract work mainly for clients in North America, or (c) such respondents merely wished to fill out a survey not intended for them. In all likelihood, the mix of respondents matches any or all of these possibilities. Indeed, it is possible that communication professionals in France are engaged chiefly in projects based in French Canada, though we doubt so for such a high proportion. In terms of native languages, 55 respondents identified English as their native tongue, 16 named French, and 10 said Spanish. Danish, German, Greek, Italian, Portuguese, Swedish, and Turkish all had one participant in the survey; Hindi had two.

Fig. 1 shows that a majority (57\%) identified themselves primarily as technical writers/communicators, $17 \%$ reported that they were primarily translators, and $12 \%$ said that they viewed themselves as both translators and technical writers/communicators. The remaining group (14\%) listed themselves as? having a wide range of job titles, from interpreter or internationalization specialist to technical publications manager or web content analyst/ editor/writer.

\section{[insert Fig. 1 about here]}

About half in this last group listed titles that tilted primarily toward translation or localization. The other half listed titles that tilted primarily toward technical writing or editing. As Mousten has noted, "a localizer in the localization industry is a term that potentially covers a plethora of job functions" $[29$, p. 36]. This problem surfaced when the Localization Industry Standards 
Association (LISA) launched the Globalization, Internationalization, Localization, and Translation (GILT) Industry's first salary survey in 2003, whose purpose was to determine average salaries for various job profiles. One major task was to delimit job descriptions to make them as applicable as possible when applicants filled in the survey [29]. Indeed, as LISA's survey itself points out, "Localizer," "Software Translator," and "Localization Specialist" can all "be used for a translator of software, but the latter can also mean a ‘Software Localization Engineer' or 'Localization Tools Specialist”' [45]. The North American survey seems to have attracted a preponderance of technical communicators: in raw numbers, 50 technical writers, 15 translators, 11 who co-identify or whose duties are mixed, and 12 who listed "Other."

The study further showed (Fig. 2) that 58\% work in an organization that is not a translation company, close to one-third (31\%) are self-employed, and 3\% work for a translation-specialty company. This last figure, though seemingly small, was probably much higher before the fields began converging. (As for how the $8 \%$ who checked "Other" define themselves, it is difficult to know what they had in mind outside of the other choices offered. One such respondent added the elucidating comment, "I work in a Language Services department of a global bank.") The vast majority of respondents were university graduates (91\%).

\section{[insert Fig. 2 about here]}

Age stood out as a factor within each group. Of those who identified themselves primarily as translators, more than half (60\%) said that they were over age 45 . In contrast, of those who identified themselves primarily as technical writers, less than one-third (31\%) said that they 
were over 45. Interestingly, of those who identified themselves as both translators and technical writers, again more than half $(55 \%)$ said that they were over 45 . It is possible that as PTSC has arisen as a distinct field, more young people have joined it but also that persons now engaging in both translation and PTSC have started to do so only later in their careers.

Indeed, an examination of question 4, on educational background, and questions 8 and 9, on time accorded to translation vs. technical writing projects, sheds some light on what may be field convergence. More than half of respondents (52\%) engaged in language studies during their education. The next closest was the arts (14\%), followed by engineering (10\%), and social sciences $(9 \%)$. The rest were spread, in fractions of descending order, across computer science, scientific studies, mathematics/physics, philosophy, economics, and medicine/health. However, those marking "Other" constituted 27\%. Of 31 responses in this category, 24 in some way mentioned language or communication, such as "English," "Communications," "Linguistics," and an array of PTSC-type fields, including "tech writing," "information systems," "information design," "technical journalism," and "tech comm." Indeed, 14 of these 24 responses (or $16 \%$ of the 88 total respondents) could be classified as technical communication areas. Because the survey allowed "Other" to be chosen along with one of the named categories, quite a few respondents who listed a PTSC area under "Other" likewise ticked off "Language studies." A preponderance of those who did were under age 45 (89\%). In responses to questions 8 and 9, regarding the development over time accorded to translation vs. technical writing, we can see that the fields were more distinct at the time that respondents began their careers and less so in 2008, at the time of the survey. The change is evident in Fig. 3: When their careers began, $23 \%$ were engaged in translation only, $58 \%$ in technical communication only, while the remaining $19 \%$ did some combination of both. 


\section{[insert Fig. 3 about here]}

The right-hand chart of Fig. 3 shows that, at the time of the survey, the percentages had shifted: $19 \%$ worked solely on translation while $49 \%$ focused solely on technical communication. Those who did some combination of both had risen to $32 \%$, or nearly onethird, suggesting either that the fields are converging or that the respondents are gaining crosstraining or experience outside their field of training and are performing tasks in both fields. Further evidence of the possibility of field convergence seems to be suggested by responses to question 14: "What percentage of the translation projects with which you've been involved in the past year can be classified as having no clear-cut source language or target languages but instead could be classified as concurrent, integrated creation of the documents in multiple languages?" Over one-third (34\%) of responses listed over $20 \%$ of their projects as having no clear-cut source language; a significant percentage (6\%) listed over $80 \%$ of their projects. Interestingly, as Fig. 4 shows, of the 82 out of 88 participants who responded to questions 15 and 16 on active and passive knowledge of a second language, a full $86 \%$ described their passive knowledge of a second language as "decisive," "useful," or "an asset," while only $11 \%$ described it as "unimportant." Similarly, 84\% described their active knowledge of a second language as "decisive," "useful," or "an asset," while only $12 \%$ described it as "unimportant." (The remaining fractions adding up to $100 \%$ selected "Other.")

\section{[insert Fig. 4 about here]}


Virtually all survey respondents answered these questions. The majority identified themselves primarily as technical communicators. Indeed, $87 \%$ consider their passive knowledge of a second language "decisive," "useful," or "an asset," and 80\% consider their active knowledge of a second language "decisive," "useful," or "an asset." (As one might expect, 100\% of those who identified themselves primarily as translators said that their knowledge of a second language was “decisive.") This survey finding provides a clue to the increasingly multilingual nature of technical documentation and the possible convergence of translation and technical communication.

\section{Cross-training for North American Translators and Professional Communicators}

Questions 12, 13, and 17 were aimed at exploring the extent of respondents' cross-training. Question 12 asked those who saw themselves primarily as translators if their education included courses or instruction in writing technical documentation. Sixty-six respondents answered. The left-hand chart in Fig. 5 shows that $50 \%$ said yes and $43 \%$ said no, while a mere 7\% said that such education did not apply to their activities. Question 13 asked those who saw themselves primarily as technical communicators if their education included courses or instruction in translation or preparing technical documents for translation. A comparison of those two groups shows (Fig. 5, right) that with remarkable near symmetry to the translators, $50 \%$ of the technical writers said yes and $47 \%$ said no. Notably, none said that such education did not apply to their activities, although $3 \%$ chose "Other" (78 respondents).

\section{[insert Fig. 5 about here]}


Of the respondents who chose "Other," one mentioned that his/her education "was in Spanish, so it included translation, but not specific to technical documents." The only other person to comment said, "As a graduate student, I did independent study on the topic of writing for international audiences (writing for translation)." Clearly, the results are mixed for both professions. About half of translators and professional communicators appear to have received some amount of cross-training, however small or large that may be, but the other half got none, even though cross-training would appear to be increasingly beneficial.

Although questions 12 and 13 were designed for those who identified primarily one profession over the other, the survey did allow those who identified themselves as both translators and technical communicators to respond. In this group, 56\% said they had had a course or instruction in writing technical documentation, and $46 \%$ said they had had a course or instruction in translation or preparing technical documents for translation. When one realizes that this group by its self-identification considers itself as fully involved in both fields/professions, the degree of cross-training seems alarmingly low. Several more comments in response to these questions are elucidating. One said, "I became a TW before there were courses for it." Another noted, "I learned about localization issues on the job; also took several language classes." Still another mentioned, "I acquired these competencies through selfdirected study in the workforce." Such statistics and comments clearly suggest that many academic programs in North America can fill a gap in their curricula and thereby address their students' future needs by including interdisciplinary instruction and cross-training.

The results for question 17 appear to provide verification. When asked if they intend, in the near future, to attend a training course or improve their skills, 34\% said they plan to do 
so in the area of translation. Additionally, $25 \%$ said they intend to improve or take a course in writing in a second language. In addition, 57\% chose "Other," sometimes listing specific specialties, such as "translation management," "translation tools," or "writing in both my native languages." (The total of percentages exceeds $100 \%$ for this question because respondents were allowed to select more than one response.) Again, when one examines PTSC's multilingual nature today and survey respondents' desire for further education and knowledge, one can see that academic programs in North America have not fully provided the interdisciplinary instruction or cross-training that current professionals find necessary or desirable. The opportunity to update curricula seems ripe.

Accordingly, question 18, inviting insights and comments of any kind, produced several enlightening observations. One noted, "I would have liked to have taken courses in translating technical material but they were not available to me." Another observed, "Technical writers should always keep in mind that their text may be translated and consider that. Due to grammar differences many times translators do not know if items should be plural in other languages." Especially notable was this comment:

At the service-provider level for translation and localization, we are seeing an increased interdependence of tech writing and translation and the need for better coordination. For certain projects, translation is also not sufficient and authoring directly in the target language(s) would likely yield a better outcome.

The European Survey Methods The European survey (Appendix B), titled "Professional Communication and Translation in Europe," aimed to answer the following questions: 
1. Have professional communication and specialist translation been converging in the European market?

2. Is there a professional migration trend from translation to technical authoring? Or is the reverse more frequently the case?

3. Would translators and technical authors need or benefit from cross-training during their studies and later on during employment? What in particular should instructors include from each of the two fields when designing academic cross-training?

Eliciting essential information on the respondents' profile, employment history, and educational background, the survey was administered to translators and technical communicators-including graduate students and junior and senior professionals-living in Europe and/or having working relations with European businesses. More precisely, the sample comprised (1) groups of technical communicators and language experts selected for their membership in professional associations and special interest communities, and (2) individuals informed by colleagues or acquaintances about the survey. Thanks to information spreading via email within communities, it was possible to obtain a highly varied sample whose tasks, profiles, work experiences, and conditions were more heterogeneous than expected.

Prospective participants included the following:

- Members of PTSC associations, their European chapters and local interest groups, among others the Society for Technical Communication and TCeurope [46], [47]; 
- Members of primary associations and communities of translators, interpreters and localizers, including, among others, the British Institute of Translation and Interpreting and the Belgian Chamber of Translators, Interpreters and Philologists [48], [49];

- Individual professionals invited to complete the survey either directly by a coauthor or indirectly by colleagues.

The European Survey Results Results collected in response to questions 4-9, 11, and 19-24 proved insightful for identifying convergence and professional migration trends. From 26 March 2008 to 15 June 2008, the survey posted on SurveyMonkey.com collected answers from 387 respondents [44]. Although we expected that most respondents would be translators, technical writers constituted a fraction not much smaller; the remaining group comprised editors, teachers, localizers, revisers, and IT experts.

Displayed as percentages in Fig. 6, the raw numbers were 160 translators (43\%), 128 technical writers $(35 \%)$, and 23 professionals with mixed duties $(6 \%)$ who declared themselves both technical writers and translators/localizers. The remaining $16 \%$ comprised professionals with duties besides translation and/or technical writing (e.g., editing).

\section{[insert Fig. 6 about here]}

Furthermore, $21 \%$ of respondents specified a different function-evidence that professional borders are frequently blurred and functions discharged are extremely varied. Specific roles 
included management and coordinating functions, profiles of language experts, researchers, administrative officers, plus specific job titles generally falling within the wide gamut of PTSC activities (e.g., information designers, usability experts, journalists, and copywriters). Answers to career development questions confirmed the trend explained above: While 88 subjects started their professional lives as technical writers, the number of subjects working as technical writers has risen to 151 (a 72\% increase). Simultaneously, self-identified translators recorded a smaller increase, from 129 to 183 subjects (a $42 \%$ increase). Quite strikingly, for localization, revision, and editing, the numbers of professionals currently in these areas were far larger than the numbers reported at career start and could be interpreted as evidence that such activities require a given level of previous work experience as entry criterion. (On the other hand, localization and revision are now an integral part of translation curricula in some programs, like those at the University of Trieste and Aarhus University.) About one-third of respondents also said that the time currently accorded in their job to translation is zero.

Respondents' second most used language was English at 69.9\%, followed by German and French, both at $18.4 \%$. Although participants identified themselves as coming from a broad range of nations (32), we note that $44 \%$ of the responses (163) came from Nordic countries: mostly Finland and Sweden, followed by Denmark, Norway, and Iceland — a much greater representation than one would expect of Europe's full array of translators and professional communicators. We cannot explain the survey's magnetism for professionals in Nordic nations, as no special initiatives were made for this region. Though grateful for the Finnish and Swedish participation, we ask our readers to consider figures with a view to Nordic influence on the survey's results. 
The study revealed that $51 \%$ of respondents were self-employed (compared to only $31 \%$ in North America), while $43.5 \%$ worked in an organization that is not a translation company (as compared to $58 \%$ in North America), and only $5.5 \%$ joined a translation company (which is comparable to $3 \%$ in North America). A large majority were university graduates (87\%), a smaller proportion than in the North American survey (91\%). All degrees represent a wide array of studies, the one most frequently mentioned (66\%) being language studies, as compared to only $52 \%$ in North America (though it could be argued that the $14 \%$ proportion of North American respondents who indicated a more general "arts" might have had language studies in their curriculum).

As in the North American survey, age structure within each profession appeared to indicate a possible migration trend: While the sample largely consisted of persons over age 45 (36\%), the number of technical writers increased as their age increased. Translators did not reveal any specific tendency across age groups. Persons to age 35 were found almost equally among translators and technical writers (respectively $30 \%$ and $31 \%$ ), while professionals aged $36-45$ made up $37 \%$ of technical writers versus $27 \%$ of translators. This age-related information may support the hypothesis that language professionals start their career as translators or language experts and then migrate to technical writing along their professional path by gaining experiences.

Two additional factors seem to support the professional migration hypothesis: the respondents' educational background (question 4) and initial profession (question 8). Question 4 allowed more answers so that it could account for mixed educational curricula, which one encounters frequently in several service industries, including technical authoring. Even so, the major categories were discernible, as shown in Fig. 7 below. 


\section{[insert Fig. 7 about here]}

Irrespective of educational level attained, a large majority $(66 \%)$ declared themselves to have been educated in language studies. The percentage increased to $69 \%$ when translation and interpreting studies were included (which 14 respondents categorized as a separate education field). The second best-scoring field of education was engineering (11\%) followed by computer science (9\%). Surprisingly, only $4 \%$ of those surveyed declared that they received an education in "technical communication" or "communication" (respectively 6 and 11 responses specified under "Other"), which equaled half the response rate for scientific studies, mathematics, or physics, taken as an aggregate (8\%). The low response counts for technical communication studies can be explained by PTSC's scarcity of university courses in Europe. Finally, the role of language proficiency in respondents' career development further supports the hypothesis of a migration trend from translation to PTSC (questions 26-27): While, obviously, language skills figure significantly in translators' lives, they are also important for technical writers not in charge of translation work. They recognized proficiency in a second language to have been crucial (70\% for active and 64\% for passive language skills) or useful (22\% for active and $28 \%$ for passive language skills) in their career development. These numbers run a close parallel to the North American survey's findings.

\section{Cross-over Language Activities and Training for European Translators and Professional}

Communicators In general, as with the North American survey findings, the European 
survey revealed that the cross-over between the activities of technical writers and translators is substantial; therefore, the two professions would greatly benefit from cross-training. Questions 12-17 inquired about respondents' positive and negative work experiences with translators and technical communicators (respectively through questions 12-14 and 15-17) and related causes of unsuccessful cooperation. Those who had already had work experience with translators, localizers, translation companies, or similar (about $70 \%$ of responses) judged their experiences not fully satisfying (46\% of responses) or disappointing (4\%). For technical communicators, $71 \%$ said they were satisfied, $27 \%$ said they were not fully satisfied, and the remaining $2 \%$ said they were disappointed.

Fig. 8 and Fig. 9 show the two groups' comments on cooperation with each other. The professionals cooperating with translators said their main cause of dissatisfaction was unrealistic deadlines or project goals (57\%), translator's or translation agency's inadequate field or product knowledge (44\%), translator's or agency's late or inadequate involvement in the project (40\%), and translator's or agency's inadequate preparation to produce and manage technical documentation (33\%). Comments under "Other" were revealing: Several claimed translation quality was often endangered by inconsistencies arising from translation agencies' inaccuracy or poor quality control, as well as excessive staff-turnover levels.

Main causes limiting translators' successful cooperation with technical writers included documentation not written with translation in mind (47\%), bad management (e.g., unrealistic deadlines or project goals) (45\%), difficulty consulting with the technical communicator on the project/product (41\%), and documentation not written in plain language (39\%).

\section{[insert Fig. 8 about here]}




\section{[insert Fig. 9 about here]}

Causes listed under "Other" included external technical writers' frequent turnover; poor quality or lack of instructions, guidelines, and specifications by the technical writer; varying qualifications as well as unavailability of technical writers with specific training in certain countries; documentation not properly structured; too theoretical an approach; and technical writing carried out from the developer's, rather than the user's, perspective.

If we compare the major reasons for both groups' frustrations, the resemblance of major problems is striking. "Deadlines and unrealistic goals" identified directly scored high in both diagrams, with $57 \%$ and $45 \%$, respectively. The points labeled "lack of consultancy" by translators can easily be paired with the reasons labeled by technical communicators as "degree of involvement low" and "lack of informing agency."

\section{Conclusions}

The surveys confirm earlier research showing that technical translators and technical communicators are increasingly seeking cross-training and engaging in work that used to be relegated to either the translation or PTSC field but not both combined [1]-[4], [6]. The results verify the legitimacy of Byrne's call for cross-training [5] and suggest that PTSC curricula include translation and localization courses and writing courses with attention to plain 
languages, usability, and structured writing. Translation curricula should include courses on managing translation/multilingual PTSC projects. Collaborative translation projects - at the heart of Kiraly's social constructivist approach to translator education-enhance students' expertise (i.e., competence to satisfy the clients' expectations) and professionalism (i.e., ability to work within the social and ethical norms of the profession) [30]. In both PTSC and translation curricula, such projects should include preparing information packages for translators (e.g., source texts, translation memories, and terminology data bases), using project management and revision tools, and adhering to norms and standards.

In general, the North American survey confirmed that translators increasingly are delving into PTSC, including drafting from scratch and/or in tandem with other translators/technical writers when no source language is identified and documents are composed in several language versions at once. For their part, professional communicators are increasingly involved in translation projects and finding themselves drawing on their knowledge of second languages and translation processes (or wishing they had such knowledge). For significant numbers of professionals handling technical documentation, the roles and fields of translation and technical communication are converging, with the expectation that such professionals are at once "translating technical writers/technical writing translators," with blended knowledge from previously discrete fields.

To a large degree, the survey's results appear to do the following:

- Confirm a trend toward convergence in North America of professional communication and translation, which require similar competencies, particularly in terms of language and communication skills; 
- Verify that the roles in Canada and the US of both translators and technical communicators are expanding, often by permeating each other's historically distinct fields, and, for some professionals, the distinction between fields is disappearing as professionals take on dual roles and tasks; in particular, the results suggest that translators in the North American market appear to be performing more and more the role of technical writer as texts are composed in multiple language versions simultaneously with no language identified as the source language;

- Reveal a desire on the part of both translators and technical communicators for crosstraining and further education in each other's fields.

In general, the European survey confirmed that most professions existing in PTSC are not clear-cut jobs with standardized and commonly understandable job titles. On the contrary, different job titles abound in the field, a fact which appears to result in limited professional visibility and indirectly contribute to increased confusion and perhaps somewhat lower standards in multilingual documentation quality in spite of quality management being considered the most important business factor in the TM-Europe 2009 survey [50]. To a large degree, the results do the following:

- Appear to confirm a convergence between PTSC and translation, which require similar competencies, particularly in terms of language and communication skills;

- Help identify a trend in professional migration from translation (or occupations requiring proficiency in foreign languages) to PTSC; nevertheless, it must be specified that professional migration schemes may not be definitive in a professional's life, as 
the current market situation often requires flexibility in taking over roles according to changing working and production conditions;

- Highlight the areas where cross-training would be most desired for both translators and technical communicators.

Against this backdrop, academic cross-training for translators, designed to familiarize students with scientific or technical information in the broader sense, seems appropriate. Such crosstraining could be attained by requesting that students regularly read, write, and report on technical and scientific documentation. With respect to the acquisition and development of specific domain-related competencies, it was surprising to note that a recent study on the employment outlooks of graduate translators and interpreters confirmed that graduates in translation studies claim a lack of adequate preparation in languages for special purposes (LSP) (even though in the 5-year curriculum, a total of 25 credits, that is, 150 hours in class, is actually devoted to LSPs [51]). Weighing all the options and needs described, universities and institutes of translation studies might consider offering introductory courses on documentation management; in particular, due attention should be paid to clear writing, strategies to properly manage and structure long documents, or designing documentation with reuse in mind. As experience in such domains can best be gained and kept up to date by maintaining regular and close relations with the industry, cross-training might be most efficiently designed and developed in cooperation with companies offering internships.

For both surveys, it must be noted that in-depth analysis of current trends and any prospect of forecasting future developments in the fields require more study. Indeed, part of our motivation in conducting the surveys has stemmed from our desire to increase awareness, 
foster discussion, and prompt a series of follow-up studies, which would paint a fuller and crisper picture of the trends and situations on our two continents and others across the globe. No matter the continent, we beckon teachers of both PTSC and translation to heed the ongoing changes in the documentation industry and adapt to the convergence of what previously were perceived to be distinct professional fields and profiles.

\section{Appendix A. Questionnaire Distributed in North America}
1. Age:
$\square$ up to 25
$\square 36-40$
$\square 26-30$
$\square 31-35$
$\square 41-45$
$\square$ over 45

2. In which country do you work?

3. What is/are your native language(s):

4. What is your educational background? :

$\square$ Language studies

$\square$ Social studies

$\square$ Philosophy

$\square$ Economics

$\square$ Law

$\square$ Mathematics/physics

$\square$ Engineering

$\square$ Scientific studies

$\square$ Medicine/health

$\square$ Arts

$\square$ Computer science

$\square$ Other (please specify):

5. Do you have a university degree? Specify: $\square$ yes $\square$ no

6. Are you (a) self-employed, (b) employed in a translation company, (c) employed in-house at a firm that is not a translation company, or (d) other?

7. Do you consider yourself primarily (a) a translator, (b) a technical writer/communicator, (c) both, or (d) other (specify)?

8. Rounding off to the ratios given, how would you proportion the time that you accord in your job to translation/technical writing? 
a. $100 \%$ translation $/ 0 \%$ technical writing

b. $75 \%$ translation $/ 25 \%$ technical writing

c. $50 \%$ translation $/ 50 \%$ technical writing

d. $25 \%$ translation $/ 75 \%$ technical writing

e. $0 \%$ translation $/ 100 \%$ technical writing

9. When you began your career, what was the proportion of time that you accorded in your job to translation/technical writing?

a. $100 \%$ translation $/ 0 \%$ technical writing

b. $75 \%$ translation $/ 25 \%$ technical writing

c. $50 \%$ translation $/ 50 \%$ technical writing

d. $25 \%$ translation $/ 75 \%$ technical writing

e. $0 \%$ translation $/ 100 \%$ technical writing

10. If you perform writing tasks in a second language, please specify how often:

$\square$ Nearly on a daily basis

$\square$ On a weekly basis

$\square$ On a monthly basis

$\square$ 3-4 times per year

$\square$ Occasionally/seldom

11. If you translate, please specify how often:

$\square$ Nearly on a daily basis

$\square$ On a weekly basis

$\square$ On a monthly basis

$\square$ 3-4 times per year

$\square$ Occasionally/seldom

12. If you consider yourself primarily a translator, did your education include courses or instruction in writing technical documentation?
a. Yes
b. No
c. Not applicable
d. Other (please specify)

13. If you consider yourself primarily a technical writer/communicator, did your education include courses or instruction in translation or preparing technical documents for translation?
a. Yes
b. No
c. Not applicable
d. Other (please specify) 
14. What percentage of the translation projects with which you've been involved in the past year can be classified as having no clear-cut source language or target languages but instead could be classified as concurrent, integrated creation of the documents in multiple languages?
a. $1-20 \%$
b. $21-40 \%$
c. $41-60 \%$
d. $61-80 \%$
e. $81-100 \%$

15. Your passive knowledge of a second language(s) in your job has proved to be:

$\square$ Decisive

$\square$ Useful

$\square$ An asset

$\square$ Unimportant

$\square$ Other (please specify)

16. Your active knowledge of a second language(s) in your job has proved to be:

$\square$ Decisive

$\square$ Useful

$\square$ An asset

$\square$ Unimportant

$\square$ Other (please specify)

17. In the near future, do you plan to attend a training course or improve your skills in $\square$ Writing in a second language

$\square$ Translation

$\square$ Other (please specify)

18. Comments: 


\section{APPENDIX B. QUESTIONNAIRE DISTRIBUTED IN EUROPE}

\section{PERSONAL DETAILS}

1. Age:

$\square$ up to 25

$\square 26-30$

$\square 31-35$

$\square 36-40$

$\square$ 41-45

$\square$ over 45

2. In which country do you work?

3. What is your native language?

4. What is your educational background?

$\square$ Language studies

$\square$ Social studies

$\square$ Philosophy

$\square$ Economics

$\square$ Law

$\square$ Mathematics/physics

$\square$ Engineering

$\square$ Scientific studies

$\square$ Medicine/health

$\square$ Arts

$\square$ Computer science

$\square$ Other (please specify): 
5. Do you have a university degree?

$\square$ Yes

$\square$ No

6. Are you (a) self-employed, (b) employed in a translation company, or (c) employed inhouse at a firm that is not a translation company?

7. What is your current profession?

$\square$ Technical writer

$\square$ Editor

$\square$ Trainer/teacher

$\square$ IT expert

$\square$ Translator

$\square$ Reviser

$\square$ Localiser

$\square$ Other (please specify):

8. What was your MAIN profession at the beginning of your career?

$\square$ Technical writer

$\square$ Editor

$\square$ Trainer/teacher

$\square$ IT expert

$\square$ Translator

$\square$ Reviser

$\square$ Localiser

$\square$ Other (please specify):

\section{WORKING CONDITIONS and FOREIGN LANGUAGES}

9. Do you use any second language at work?

$\square$ Yes

$\square$ No

[If the respondent chooses NO, he/she is automatically directed to question 28]

10. Please specify your second language(s) used:

$\square$ Dutch

$\square$ English

$\square$ French

$\square$ German 
$\square$ Italian

$\square$ Spanish

$\square$ Other (please specify):

11. Which activities do/did you perform in your second language(s) in your current/previous job(s):

$\square$ Reading/studying materials

$\square$ Producing materials

$\square$ Translating from a second language into your native language

$\square$ Translating from your native language into a second language

$\square$ Proofreading/editing materials translated into a second language

$\square$ Proofreading/editing materials translated into your native language

$\square$ Usability testing

$\square$ Localising products

$\square$ Preparing documentation for translation/localisation

$\square$ Other (please specify):

12. Have you ever worked with a (team of) translator(s)/localiser(s), a translation agency or similar?

$\square$ Yes

$\square$ No

[If the respondent chooses NO, he/she is automatically directed to question 15]

13. How do you consider your work experience with translators or translation agencies?

$\square$ Satisfying

$\square$ Not fully satisfying, to be improved

$\square$ Disappointing

[If the respondent chooses SATISFYING, he/she is automatically directed to question 15]

14. Could you please identify the main cause(s) of unsuccessful cooperation in your opinion?

$\square$ Too short deadlines or unrealistic project goals

$\square$ Late or inadequate involvement of the translator/agency in the project

$\square$ Inadequate field/product knowledge of the translator/agency

$\square$ Inadequate preparation of the translator/agency to produce and manage technical documentation

$\square$ Other (please specify):

15. Have you ever worked with a (team of) technical writer(s)/communicator(s) or similar?

$\square$ Yes 
$\square$ No

[If the respondent chooses NO, he/she is automatically directed to question 18]

16. How do you consider your work experience with technical writers/communicators?

$\square$ Satisfying

$\square$ Not fully satisfying, to be improved

$\square$ Disappointing

[If the respondent chooses SATISFYING, he/she is automatically directed to question 18]

17. Could you please identify the main cause(s) of unsuccessful cooperation in your opinion?

$\square$ Too short deadlines or unrealistic project goals

$\square$ Difficulty to consult with the technical writer/ communicator on the project/product on a regular basis

$\square$ The documentation is not written with translation in mind

$\square$ The documentation is not written with localisation in mind

$\square$ The documentation is not written in plain language

$\square$ Other (please specify):

18. How often do you use your second language(s) at work?

$\square$ On a daily basis

$\square$ On a weekly basis

$\square$ On a monthly basis

$\square$ Occasionally

19. Please specify ratio of usage of native language versus second language(s) at work (total work activities):

$\square 10 \%$ native language- $-90 \%$ second language(s)

$\square 30 \%$ native language $-70 \%$ second language $(\mathrm{s})$

$\square 50 \%$ native language $-50 \%$ second language(s)

$\square 70 \%$ native language- $30 \%$ second language(s)

$\square 90 \%$ native language-10\% second language(s)

20. If you perform translation tasks, please specify how often:

$\square$ Nearly on a daily basis

$\square$ On a weekly basis

$\square$ On a monthly basis

$\square$ 3-4 times per year

$\square$ Occasionally/seldom 
21. If you perform editing/proofreading tasks in a second language, please specify how often:

$\square$ Nearly on a daily basis

$\square$ On a weekly basis

$\square$ On a monthly basis

$\square$ 3-4 times per year

$\square$ Occasionally/seldom

22. If you perform writing tasks in a second language, please specify how often:

$\square$ Nearly on a daily basis

$\square$ On a weekly basis

$\square$ On a monthly basis

$\square$ 3-4 times per year

$\square$ Occasionally/seldom

23. Rounding off to the ratios given, how would you proportion the time that you accord in your job to translation/other activities?

$\square 100 \%$ translation/0\% other activities

$\square 75 \%$ translation $/ 25 \%$ other activities

$\square 50 \%$ translation $/ 50 \%$ other activities

$\square 25 \%$ translation $/ 75 \%$ other activities

$\square 0 \%$ translation/ $100 \%$ other activities

24. When you began your career, what was the proportion of time that you accorded in your job to translation/other activities?

$\square 100 \%$ translation/0\% other activities

$\square 75 \%$ translation $/ 25 \%$ other activities

$\square 50 \%$ translation $/ 50 \%$ other activities

$\square 25 \%$ translation $/ 75 \%$ other activities

$\square 0 \%$ translation $/ 100 \%$ other activities

25. What percentage of the translation projects in which you've been involved in the past year can be classified as having no clear-cut source language or target languages but instead could be classified as concurrent, integrated creation of the documents in multiple languages?

$\square 1-20 \%$

$\square 21-40 \%$

$\square 41-60 \%$

$\square 61-80 \%$

$\square 81-100 \%$

26. Your PASSIVE knowledge of your second language(s) in your career has proved to be: 
$\square$ Crucial

$\square$ Useful

$\square$ Not essential

$\square$ Unimportant

27. Your ACTIVE knowledge of your second language(s) in your career has proved to be:

$\square$ Crucial

$\square$ Useful

$\square$ Not essential

$\square$ Unimportant

28. In the near future, do you plan to attend a training course or improve your skills in:

$\square$ A second language

$\square$ Writing in a second language

$\square$ Translation

$\square$ I have no training plan

$\square$ Other (please specify):

29. Comments:

\section{References}

[1] G. M. Shreve, "Translation at the millennium: Prospects for the evolution of a profession," in Paradigmenwechsel in der Translation: Festschrift für Albrecht Neubert zum 70. Geburtstag, P.A. Schmitt, Ed. Tübingen, Germany: Stauffenburg, 2000, pp. 217-234.

[2] G. Hofer, "Fachübersetzen in der Hochschulweiterbildung: Zum Zertifikatslehrgang ‘Fachübersetzen' an der Zürcher Hochschule für Angewandte Wissenschaften,' Trans-Kom, vol. 2, no. 1, pp. 92-108, 2009.

[3] C. Groethuysen, "Real-life training for translators: Software localisation and technical documentation," in Training the Language Services Provider for the New Millennium, B. Maia, 
J. Haller, and M. Ulrych, Eds. Porto, Portugal: Faculdade de Letras da Universidade do Porto, 2002, pp. 81-88.

[4] M. Gnecchi, "Specialized translation and technical communication: Convergence and challenges for Europe,” presented at FORUM, Milan, Italy, June 30-July 2, 2003.

[5] J. Byrne, Technical Translation: Usability Strategies for Translating Technical Documentation, Dordrecht, the Netherlands: Springer, 2006.

[6] B. Maylath, "A wake-up call: Adjusting tech comm curricula to stem the offshore flow of documentation work," presented at the Conf. of the Association of Teachers of Technical Writing, San Antonio, TX, USA, March 24, 2004.

[7] Department of Foreign Languages and Linguistics. (30 April, 2004). Graduate Certificate in Translation Studies. University of Wisconsin, Milwaukee. [Online]. Available: http://www.uwm.edu/Dept/GCIT/index.html

[8] J. Humbley, B. Maylath, B. Mousten, S. Vandepitte, and L. Veisblat, "Learning localization through trans-Atlantic collaboration," in Proceedings of the IEEE International Professional Communication Conference, 2005, pp. 578-595.

[9] B. Maylath, S. Vandepitte, and B. Mousten, "Growing grassroots partnerships: TransAtlantic collaboration between American instructors and students of technical writing and 
European instructors and students of translation," in Designing Global Learning

Environments: Visionary Partnerships, Policies, and Pedagogies, D. Stärke-Meyerring and M. Wilson, Eds. Rotterdam, the Netherlands: Sense Publishers, 2008, pp. 52-66.

[10] B. Mousten, S. Vandepitte, and B. Maylath, "Intercultural collaboration in the transAtlantic project: Pedagogical theories and practices in teaching procedural instructions across cultural contexts," in Designing Global Learning Environments: Visionary Partnerships, Policies, and Pedagogies, D. Stärke-Meyerring and M. Wilson, Eds. Rotterdam, the Netherlands: Sense Publishers, 2008, pp. 129-144.

[11] B. Mousten, "CCVT Editing and Revision of Texts," presented at the Conf. of the European Society for Translation Studies, Ljubljana, Slovenia, September 3-5, 2007.

[12] J. Payne, "Revision as a teaching method on translation courses," in Translation in the Modern Languages Degree, H. Keith and I. Mason, Eds. London, England: Centre for Information on Language Teaching and Research, 1987, pp. 43-51.

[13] B. Mossop, “Goals of a revision course," in Teaching Translation and Interpreting: Training, Talent and Experience, C. Dollerup and A. Loddegaard, Eds. Amsterdam, the Netherlands: John Benjamins, 1992, pp. 81-90.

[14] B. Mossop, Revising and Editing for Translators, 2nd ed. Manchester, England: St. Jerome, 2007. 
[15] J. T. Hine, "Teaching text revision in a multilingual environment," in Beyond the Ivory Tower: Rethinking Translation Pedagogy, B. J. Baer and G. S. Koby, Eds. ATA Scholarly Monograph Series, Amsterdam, the Netherlands: John Benjamins, 2003, pp. 135-156.

[16] I. Garcia, "Translating and revising for localization: What do we know? What do we need to know?" Perspectives: Studies in Translatology, vol. 16, nos. 1-2, pp. 49-60, 2008.

[17] G. S. Koby, "Editor's introduction—Post-editing of machine translation output: Who, what, why and how (much)," in Repairing Texts: Empirical Investigations of Machine Translation Post-editing Processes, by H.P. Krings. Translated by G.S. Koby, G.M. Shreve, K. Mischerikow, and S. Litzer. Kent, OH: The Kent State University Press, 2001, pp. vii-x.

[18] European Commission DG Translation. European Master's in Translation (EMT). [Online]. Available: http://ec.europa.eu/dgs/translation/programmes/emt/index_en.htm

[19] S. Bernardini and S. Castagnoli, "Corpora for translator education and translation practice," in Topics in Language Resources for Translation and Localisation, E. YusteRodrigo, Ed. Amsterdam, the Netherlands: John Benjamins, 2008, pp. 39-55.

[20] C. Colominas and T. Badia, "The real use of corpora in teaching and research contexts," in Topics in Language Resources for Translation and Localisation, E. Yuste-Rodrigo, Ed. Amsterdam, the Netherlands: John Benjamins, 2008, pp. 71-88. 
[21] R. Gauton, "The use of corpora in translator training in the African language classroom: A perspective from South Africa," in Topics in Language Resources for Translation and Localisation, E. Yuste-Rodrigo, Ed. Amsterdam, the Netherlands: John Benjamins, 2008, pp. $89-116$.

[22] Š. Vintar, “Corpora in translation: A Slovene perspective," JoSTrans, no. 10, pp. 40-55, 2008.

[23] Corpus Use and Translating: Corpus Use for Learning to Translate and Learning Corpus Use to Translate, vol. 82, A. Beeby, P. R. Inés, and M. P. Sánchez-Gijón, Eds. Amsterdam, the Netherlands: John Benjamins, 2009.

[24] D. Gouadec, Translation as a Profession. Amsterdam, the Netherlands: John Benjamins, 2007.

[25] H. Risku, "Migrating from translation to technical communication and usability," in Claims, Changes and Challenges in Translation Studies: Selected Contributions from the EST Congress, Copenhagen 2001, G. Hansen, K. Malmkjær, D. Gile Eds. Amsterdam, the Netherlands: John Benjamins, 2004, pp. 181-195.

[26] H. Risku, Translatorische Kompetenz: Kognitive Grundlagen des Übersetzens als Expertentätigkeit. Tübingen, Germany: Stauffenburg, 1998. 
[27] J. Swales, Genre Analysis: English in Academic and Research Settings. Cambridge, UK: Cambridge University Press, 1990.

[28] T. Dudley-Evans, "Genre analysis: An approach to text analysis for ESP”, in Advances in Written Text Analysis, M. Coulthard, Ed. London, England: Routledge, 1994, pp. 219-228.

[29] B. Mousten, “Globalisation and localisation influences on web site text distribution: A case study of text travel between two VELUX web sites,” Ph.D. dissertation, Copenhagen Univ., Copenhagen, Denmark, 2008.

[30] D. Kiraly, A Social Constructivist Approach to Translator Education. Manchester, UK: St. Jerome, 2000.

[31] D. Katan, Translating Cultures: An Introduction for Translators, Interpreters and Mediators, 2nd ed. Manchester, UK: St. Jerome, 2004.

[32] M. Paretti, L. McNair, and L. Holloway-Attaway, "Teaching technical communication in an era of distributed work: A case study of collaboration between U.S. and Swedish students," Technical Communication Quarterly, vol. 16, no. 3, pp. 327-352, 2007.

[33] J. Melton, "Lost in translation: Professional communication competencies in global training contexts," IEEE Transactions on Professional Communication, vol. 51, no. 2, pp. 198-214, 2008. 
[34] Z. Nyiri and R. Clark. Web survey design: Comparing static and interactive survey instruments. Presented at the annual meeting of the American Association for Public Opinion Research, 2003. [Online]. Available: http://www.allacademic.com/meta/p116316_index.html

[35] A. Fink, How to Conduct Surveys: A Step-by-Step Guide, 3rd ed., Thousand Oaks, CA: Sage Publications, 2006.

[36] Society for Technical Communication Academic Community Special Interest Group. [Online]. Available:

http://www.stc.org/about-stc/leadership/communities/item/academic?category_id=38

[37] The Association of Teachers of Technical Writing. [Online]. Available: http://www.attw.org/

[38] The Canadian Association of Teachers of Technical Writing/ l'Association Canadienne des Professeurs de Rédaction Technique et Scientifique. [Online]. Available: http://cattwacprts.mcgill.ca/en/home.htm

[39] The Council for Programs in Technical and Scientific Communication. [Online]. Available: http://www.cptsc.org 
[40] The American Translation Association. [Online]. Available:

http://www.atanet.org/divisions/index.php

[41] Translation World. [Online]. Available: http://www.translationworld.com

[42] Globalization and Localization Association. [Online]. Available: http://www.galaglobal.org

[43] AILIA The Language Industry Association / l'Association de l'Industrie de la Langue. [Online]. Available: http://secure.ailia.ca

[44] SurveyMonkey.com. [Online]. Available: http://www.surveymonkey.com

[45] I. Larsen. (2003, January). The LISA salary survey. Globalization Insider, vol. XII, no.

1.2. [Online]. Available: http://www.lisa.org/globalizationinsider/2003/01/the_lisa_salary.html

[46] Society for Technical Communication. [Online]. Available: http://www.stc.org

[47] TCeurope. [Online]. Available: http://www.tceurope.org

[48] Institute of Translation and Interpreting. [Online]. Available:

http://www.iti.org.uk/indexMain.html 
[49] Belgian Chamber of Translators, Interpreters and Philologists. [Online]. Available: http://www.translators.be/index.php?lang=en

[50] P. Reynolds and M. Popio ${ }^{3}$ ek, "TM-Global Translation and Localisation Market Survey 2009," unpublished manuscript, 2009.

[51] S. Pionetti, "Indagine sugli Sbocchi Lavorativi dei Laureati della S.S.L.M.I.T. dall'a.a. 2001/2002 all'a.a.2005/2006," unpublished degree dissertation Academic Year 2007/2008, Scuola Superiore di Lingue Moderne per Interpreti e Traduttori, Università degli Studi di Trieste. 